\title{
A Review of Measures of Aggregate Mental Health Costs in Canada
}

\section{Mesurer les coûts agrégés liés à la santé mentale au Canada : un examen de la question}

\author{
Philip Jacobs \\ University of Alberta \\ Francine Knoops \\ Mental Health Commission of Canada \\ Alain Lesage \\ Université de Montréal
}

La version Française suit

\begin{abstract}
Since 2000, 5 studies have been published that each purported to estimate aggregate national mental health costs in Canada. Each of these studies used a different method. Our aim was to compare the studies, and we created a framework for the different elements used to assess mental health costs (direct costs, indirect costs, transfer payments, and "human" costs). In addition, each study used different parameters (population covered, diagnosis) and cost components to estimate the economic impact of mental health. Our framework can help analysts to understand the purpose of different cost components. We conclude that to achieve a consensus on the magnitude of mental health costs, we need to use more standardized approaches.
\end{abstract}

Keywords: Economic burden, mental health, cost

Philip Jacobs, Department of Medicine, University of Alberta, Edmonton, Alberta. Francine Knoops, Mental Health Commission of Canada, Ottawa, Ontario. Alain Lesage, Department of Psychiatry, Université de Montréal, Montreal, Quebec.

This project was funded with a contract between the Mental Health Commission of Canada and the Institute of Health Economics. None of the authors have any competing interest.

Correspondence concerning this article should be addressed to Philip Jacobs, Institute of Health Economics, 1200-10405 Jasper Avenue, Edmonton, Alberta T5J 3N4. Email: pjacobs@ihe.ca 


\section{RÉSUMÉ}

Depuis 2000, 5 études ont été publiées sur l'estimation des coûts agrégés liés à la santé mentale au Canada, et elles utilisent toutes des méthodes différentes. Comme notre objectif était de comparer ces études et leurs résultats, nous avons conçu un cadre qui regroupe tous les éléments des coûts à évaluer (coûts directs, coûts indirects, paiements de transfert et coûts « humains »). Nous avons tenu compte du fait que les études retenues ne s'appuient pas sur les mêmes paramètres (ex. : la population concernée, la définition de la maladie mentale) ni sur les mêmes éléments de coût. Notre cadre d'analyse permet ainsi d'aider les chercheurs à mieux comprendre les liens que l'on doit établir entre les différents éléments de coût à considérer et l'utilisation que l'on veut faire de la mesure obtenue. En conclusion, nous soulignons que, pour qu'il soit possible d'obtenir un consensus sur les coûts liés à la santé mentale, il est nécessaire de concevoir et d'utiliser des méthodes standard acceptées par tous.

Mots clés : fardeau économique, santé mentale, coût

Canadian mental health policymakers are faced with a confusing and contradictory array of aggregate measures of mental health costs. There are a vast range of estimates of the national "economic burden" of mental health, from \$12.3 billion annually (Public Health Agency of Canada, 2014) to \$2.53 trillion over a period of 20 years (Smetanin et al., 2011). Equally confusing is the fact that even though three studies concluded that the total cost as published is approximately $\$ 50$ billion (unadjusted for inflation) annually (Conference Board of Canada, 2012; Lim, Jacobs, Ohinmaa, Schopflocher, \& Dewa, 2008; Mental Health Commission of Canada, 2013), they used widely different cost components and methods to arrive at approximately the same total. In the case of Lim et al. (2008) these were historical (2001) costs, which increase to $\$ 65$ billion (Table 2) when inflated to the year 2015. Deraspe (2013), in a federal Parliamentary Library review, commented on the lack of consensus about what should go into various categories of costs, making it impossible to compare the different studies. In Making the Case for Investing in Mental Health in Canada, the Mental Health Commission of Canada (MHCC) (2013) indicated that cost studies need to be more comprehensive to better help guide policy and assess budgetary impact. The challenge of making meaning out the array of estimated aggregate costs resurfaced in efforts to update the MHCC's case for investment (Mental Health Commission of Canada, 2017). The MHCC wanted to provide policymakers with a clearer picture of current costs to inform decisions about where to invest the new funds targeted for mental health made available by the federal government through the 2017 Health Accord.

In Canada, there are no agreed-upon standard methods for undertaking aggregate-level analyses in the field of mental health, as is the case in the field of disease costing in general. While there are standard methods for measuring costs and evaluating the economic impact of specific interventions (Canadian Agency for Drugs and Technologies in Health, 2016), these do not apply to aggregate-level analyses. Even where standards for aggregate costing of production have been set by international agencies (European Commission, International Monetary Fund, Organisation for Economic Co-operation and Development, United Nations, \& World Bank, 2009) and by United States investigators (Hodgson \& Meiners, 1982), these measures do not recognize the different uses of aggregate healthcare costing. Different purposes will require use of different cost categories or components. The first step, therefore, is to define and articulate clearly the purpose 
of a study in order to align the appropriate cost measures (Bloom et al., 2011). The purpose of this paper is to review the Canadian literature on aggregate mental health costs and assess the different measures against the different purposes for which they can be used. Once these concepts are clarified, it will be possible to begin to develop standard measures and methods of estimating aggregate mental health costs.

\section{METHODS}

Aggregate economic measures of mental health in Canada from 2000 to 2015 were obtained from a literature and grey literature search. Drawing on health economics frameworks, types of costs used in the studies were divided into four groups: direct costs, indirect costs, transfer payments, and human costs. The first two groups (direct and indirect costs) are composed only of economic costs, which are the costs of resource use. Direct costs are costs of goods and services such as hospital care, physician services, and pharmaceuticals. Indirect costs are primarily the value of loss experienced in daily activities by patients or caregivers; that is, they represent the costs of resources (labour time) that are foregone because of illness. Investigators usually measure lost-activities loss in terms of lost work rather than leisure. Work loss can be experienced as absenteeism (loss of work time) and presenteeism (a reduction of productivity during continued work time). Transfer payments are not economic costs; rather, they reflect a transfer of purchasing power from government to persons - there are no services exchanged or foregone. An example of a transfer is a Canada Pension Plan payment to someone who is disabled. There is no resource use that is directly associated with the payment. Finally, human costs are also not economic costs; they are simply a subjective money measure of a person's loss of well-being. Often, however, these losses are monetized for public-interest purposes, such as in court directives. Culyer (2014) offers detailed definitions of all of these terms.

There are different valuation methods associated with each of the cost categories. Direct cost valuations involve goods and services that can be measured in the product market, such as physician fees, drug prices, and hospital Case Mix Group (CMG) payments. When the government simply provides the service, the general approach is a production function approach, which identifies the resources or inputs that are required to produce the services (European Commission et al., 2009, p. 438). Inputs can be measured in terms of resources such as labour time, supplies, and capital, or in terms of intermediate services such as hospital days and physician services. Each input is valued at its price and then the products of input quantity and price are summed for the total service price (called micro-costing or bottom-up costing). Alternatively, all costs of resources for a given bundle of services within a budget area can be summed and averaged over all of the services in the bundle (called top-down costing). Indirect costs are valued as replacement costs or opportunity costs of the workers or caregivers (the amount that the workers or caregivers could have earned in the next best employment for the allotted time). Work time that is lost can alternatively be measured as human capital costs (the full value of time off work) or friction costs (the value of lost time off from work until the worker is replaced). Transfer payments are valued as the money amount that is transferred from the government agency. Human costs are subjectively measured.

Costs can be assessed many ways for a variety of purposes. One key purpose is to provide a measure of burden. The overall burden is a monetary magnitude of the loss of resources or pain suffered because of mental illness. The economic burden is the use or loss of resources due to illness or because of care. There are a variety of different meanings and measures of economic burden. One of the most common ones is 
the amount paid by private payers for mental health services in relation to the total expenditures (for direct costs) for mental health services. A somewhat more limited variation of this measure is the amount paid by consumers out-of-pocket (that is, excluding private insurance payments) compared to total direct expenditures. Indirect costs and human costs can also be included in other measures of burden. Human costs are not considered part of the economic burden. One can also deduct transfer payments made to consumers from their direct plus indirect costs for yet another burden measure; this would be tantamount to a measure of the private burden.

Second, costs are used in the creation of budgets, which are tied to a specific paying agency and are the measure of costs of specific endeavours, such as providing an expanded community mental health program. Budgets measure whatever the agencies pay for, which include direct costs and transfers made by the agency or by government to the consumers. In the area of mental health, however, mental health services are paid for by a number of separate agencies such as health ministries, social service agencies, justice ministries, and education departments. As a result, mental health costs are scattered with respect to the origin of the payers, and are difficult to pull together into a single mental health budget.

Resource use is a third type of cost measure. The narrowest measure of the cost of resource use is for direct resources used to implement specific initiatives or policies. For example, a policy that results in the dehospitalization of mental health patients would result in lower hospital costs but higher community costs. Dehospitalization might also result in higher costs to the justice system and social services. A comprehensive resource-use measure would take into account both costs of resources that are reduced and those that are increased, regardless of the agency that provides them. An expanded measure might go beyond the strict direct measure and include indirect costs of persons with mental health caregivers. Because transfer payments and human costs do not directly measure resource use, they would not be included in this category.

A fourth use of costs is benchmarking. Benchmarking involves a comparison of mental health cost measures among regions. One such measure is total direct mental health expenditures per capita. A second indicator is direct mental health costs divided by direct total health costs; this measure is widely used in international comparisons, such as by the Organisation for Economic Co-operation and Development (2016).

We surveyed studies on the aggregate cost of mental health that have been made available since 2000 . We abstracted the mental health conditions these studies represented and the cost items included. We adjusted aggregate costs to 2015 price levels, using the Canadian Consumer Price Index from Statistics Canada (2016). We list the studies and their data sources in Table 1 and present the estimates by cost category in Table 2.

\section{RESULTS}

We identified five different estimates of national mental health costs for Canada (Table 1). Lim et al. (2008), the Institute of Health Economics (IHE) (2010), and the Conference Board (2012) used a narrow definition of mental illness, focusing on depression, anxiety, schizophrenia, and/or substance abuse. The Public Health Agency of Canada (PHAC) (2014) used a very broad definition, including all neuropsychiatric conditions. RiskAnalytica (Smetanin et al., 2011) used two different definitions: a narrow one, similar to IHE's, in estimating costs for the major mental illnesses, and a broad one that includes cognitive impairments, 


\section{Table 1}

\section{List of Included Studies and Selected Characteristics}

\begin{tabular}{|c|c|c|c|}
\hline $\begin{array}{l}\text { Study and year } \\
\text { of data }\end{array}$ & Conditions & $\begin{array}{l}\text { Population groups } \\
\text { included }\end{array}$ & Data sources \\
\hline $\begin{array}{l}\text { Lim et al. } \\
\text { (2008): } 2001 \\
\text { data. }\end{array}$ & $\begin{array}{l}\text { Any of mood disorder, anxi- } \\
\text { ety disorder, schizophrenia, } \\
\text { diagnosed and not diagnosed, } \\
\text { self-reported data. }\end{array}$ & Age 16 and up & $\begin{array}{l}\text { Canadian Community Health Survey, } \\
\text { 2003. Survey persons over } 15 \text {. }\end{array}$ \\
\hline $\begin{array}{l}\text { PHAC (2014): } \\
2008 \text { data }\end{array}$ & $\begin{array}{l}\text { Broad range of neuropsy- } \\
\text { chiatric disorders, services } \\
\text { attributable to disease only }\end{array}$ & Total population & $\begin{array}{l}\text { Hospital and doctor visits from CIHI. } \\
\text { Work loss from personal surveys. }\end{array}$ \\
\hline $\begin{array}{l}\text { IHE (2010): } \\
2007 \text { data }\end{array}$ & $\begin{array}{l}\text { All mental health service } \\
\text { users. }\end{array}$ & Total population & $\begin{array}{l}\text { Direct costs from CIHI and government } \\
\text { agencies. }\end{array}$ \\
\hline $\begin{array}{l}\text { Conference } \\
\text { Board (2012) }\end{array}$ & Depression and anxiety & $\begin{array}{l}\text { Employed workforce } \\
\text { only }\end{array}$ & $\begin{array}{l}\text { Canadian Community Health Survey and } \\
\text { Conference Board estimates of costs. }\end{array}$ \\
\hline $\begin{array}{l}\text { Risk Analytica } \\
\text { for MHCC } \\
\text { (Smetanin et } \\
\text { al., 2011) }\end{array}$ & $\begin{array}{l}\text { Two separate groups: } \\
\text { A. Cognitive impairment } \\
\text { including dementia. } \\
\text { B. Other mental illnesses. }\end{array}$ & Same as IHE (2010) & $\begin{array}{l}\text { Cognitive impairment based on Holland- } \\
\text { er (2002) and other mental illness based } \\
\text { on Jacobs (2010). }\end{array}$ \\
\hline
\end{tabular}

including dementia. The cost items that were included also vary widely. These are listed in Table 1 and Table 2. Data sources are also listed in Table 1.

Just as there is a wide range of ways to define "economic cost" for mental illness, there is a wide range of estimates. As seen in Table 2, the range of costs in 2015 dollars goes from \$13.5 billion (Public Health Agency of Canada, 2014) to $\$ 65.3$ billion (Lim et al., 2008). Each study includes a unique array of diseases and of cost items, however. For example, in the two lowest estimates, the Public Health Agency of Canada (2014) has the broadest range of illnesses, including virtually all neurological disorders, while the Institute of Health Economics (2010) bases its estimate on a narrow definition of mental illness. The cost items differ in that PHAC includes indirect costs, while IHE excluded these but includes transfer payments. Similarly, RiskAnalytica (Smetanin et al., 2011) and the Conference Board (2012) both have values of just over $\$ 50$ billion, but RiskAnalytica has a very wide definition of illnesses, including dementia, while the Conference Board includes only depression and anxiety. RiskAnalytica's estimates are focused primarily on expenses for services, although it does have an indirect component for dementia. Lim et al. (2008) use a narrower definition of disease but include indirect costs and human costs, which are significant contributors to the overall measure of $\$ 65.3$ billion.

Studies also varied by inflation adjustors. RiskAnalytica (Smetanin et al., 2011) used a fixed rate of inflation for all years - one that was developed in 2005 when inflation was higher than in subsequent years. This paper uses a general consumer price index, which is available for all years and all studies. 


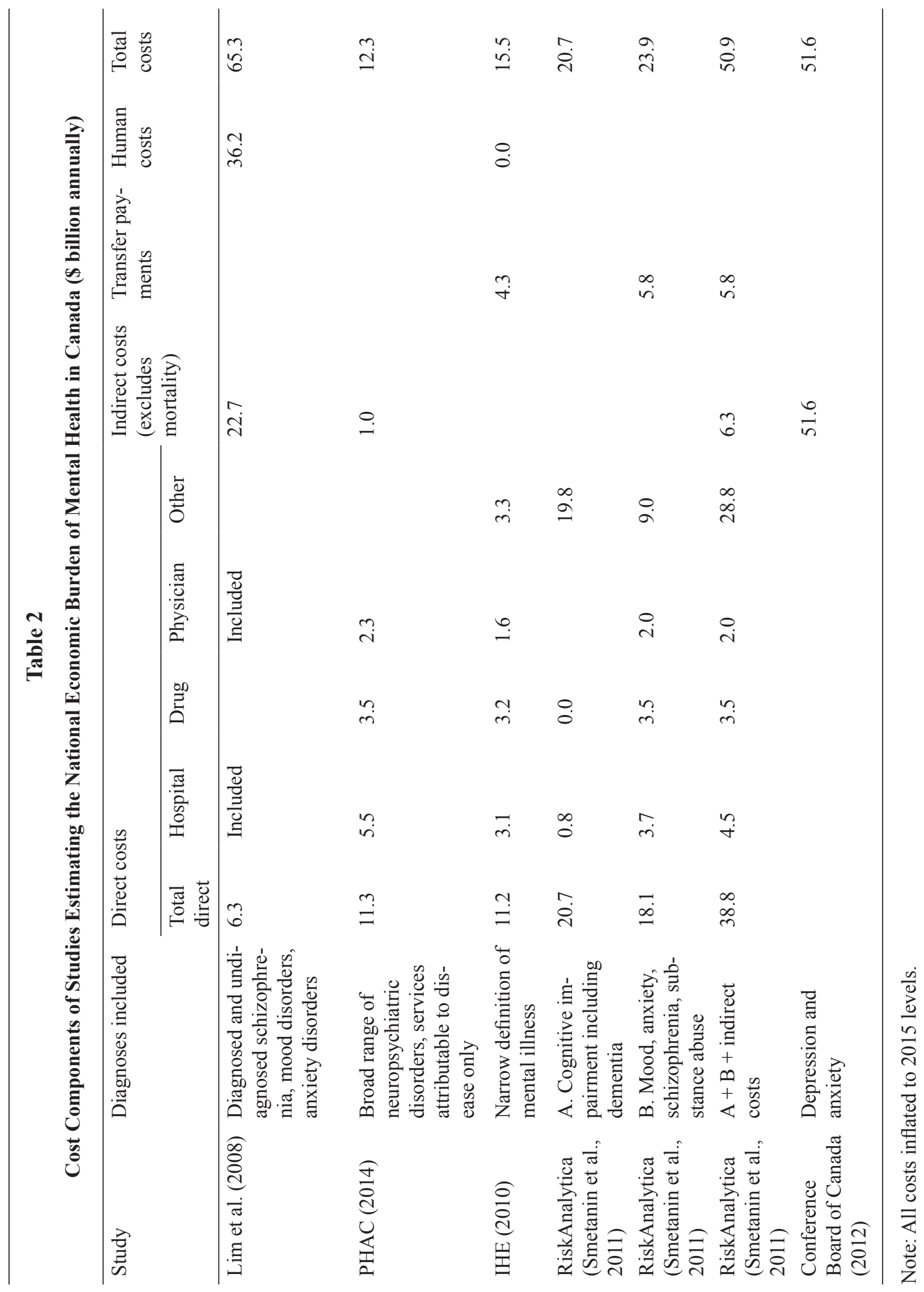




\section{DISCUSSION}

Agencies and researchers in Canada have released several estimates of the cost of mental illness in Canada. Some of the studies vary widely in the size of the estimates, but even in studies where estimates were similar the items that were included varied considerably, raising questions about which measure of aggregate cost is appropriate. In this paper we have reviewed and compared the components and estimates of each of the studies. We have indicated that there are different measures of aggregate cost, and that the investigator's purpose will determine which measure is used. By identifying the various purposes, and linking costs to them, we can develop a clearer idea about which costs we should include. Essentially, no single costing strategy could serve all purposes.

If the purpose of the estimate is budgeting, then direct costs and transfer payments should be used in the estimates; these both represent a public agency's expenses. If the analyst wants to answer a resource-use question, then cost estimates would include direct costs and indirect costs. It should be noted, however, that the study perspective (e.g., public resources) might call for the inclusion of only direct costs. For example, if researchers want to estimate the resource impact of closing beds and replacing inpatient care with community care, then they should focus on direct costs only. Similarly, in the costing of the replacement of specialist care with primary care, the analyst will estimate the direct costs of each type of care and compare them. Resource-use estimates can go well beyond the health sector. Mental illness has an impact in the education, criminal justice, and social services sectors, and costs of these services can be factored into the analysis as well. Resource-use questions are often framed in the form of cost-effectiveness studies; they are rarely formulated in aggregate terms.

The third use of aggregate cost estimates is to measure the economic burden. Most of the studies we reviewed were attempts to demonstrate the magnitude of the economic burden of mental illness; thus, the Conference Board measured absenteeism and presenteeism costs, and RiskAnalytica (Smetanin et al., 2011) measured future direct costs of mental illness and dementia, all of which are indicators of the economic burden. Economic burden studies can also incorporate caregiver costs, which are resource costs. Lim et al. (2008) included human costs as part of the burden; strictly speaking, however, these are not resource costs and therefore not part of the economic burden of mental illness. The fourth type of cost is associated with benchmarking. The Institute of Health Economics (2010) used its costs to compare the ratio of mental health costs to total health care costs for a number of countries. Most countries use only direct resource costs in their benchmarking estimates (Organisation for Economic Co-operation and Development, 2016). Another common benchmarking measure is the per capita mental health direct costs (Institute of Health Economics, 2010); this measure has been used to compare the magnitude of resource use across provinces.

\section{CONCLUSION}

There are two major problems with respect to measuring aggregate mental health costs in Canada: the lack of standards and lack of adequate data. Although standards are available in other jurisdictions, these have not been used in any of the Canadian studies. Canadian researchers can build on standards for collecting economic data for direct costs as presented in the United Nations System of National Accounts (European Commission et al., 2009). We can also refer to the United States Public Health Service publications 
on standards for measuring the economic burden of illness (Hodgson \& Meiners, 1982). However, these standards require better data on mental health care use, and in Canada there are very poor data on outpatient or community mental health services. The best data come from health departments for services that are medically necessary. In mental health, however, data from many services, even those funded by the health ministries, have not been made publicly available. Lastly, cost data on some important available data on mental health services, such as those provided within the justice and social services ministries, have not been made publicly available.

\section{REFERENCES}

Bloom, D. E., Cafiero, E. T., Jané-Llopis, E., Abrahams-Gessel, S., Bloom, L. R., Fathima, S., . . Weinstein, C. (2011). The global economic burden of noncommunicable diseases. Geneva, Switzerland: World Economic Forum.

Canadian Agency for Drugs and Technologies in Health. (2016). Guidance document for the costing of health care resources in the Canadian setting (2nd ed.). Ottawa, ON: Author.

Conference Board of Canada. (2012). Mental health issues in the labour force: Reducing the economic impact on Canada. Ottawa, ON: Author.

Culyer, A. J. (2014). The dictionary of health economics (3rd ed.). Cheltenham, England: Edward Elgar.

Deraspe, R. (2013). Current issues in mental health in Canada: The economic impact of mental illness. Publication no. 2013-87-E. Ottawa, ON: Library of Parliament.

European Commission, International Monetary Fund, Organisation for Economic Co-operation and Development, United Nations, \& World Bank. (2009). System of National Accounts 2008. New York, NY: Authors.

Hodgson, T. A., \& Meiners, M. R. (1982). Cost-of-illness methodology: A guide to current practices and procedures. Memorial Fund Quarterly, Health and Society, 60(3), 429-462.

Institute of Health Economics. (2010). The cost of mental health and substance abuse services in Canada. Edmonton, AB: Author.

Lim, K.-L., Jacobs, P., Ohinmaa, A., Schopflocher, D., \& Dewa, C. S. (2008). A new population-based measure of the economic burden of mental illness in Canada. Chronic Diseases in Canada, 28(3), 92-97.

Mental Health Commission of Canada. (2013). Making the case for investing in mental health in Canada. Calgary, AB: Author. Retrieved from https://www.mentalhealthcommission.ca/sites/default/files/2016-06/Investing_in_ Mental_Health_FINAL_Version_ENG.pdf

Mental Health Commission of Canada. (2017). Strengthening the case for investing in Canada's mental health system: Economic considerations. Calgary, AB: Author. Retrieved from https://www.mentalhealthcommission.ca/sites/ default/files/2017-03/case_for_investment_eng.pdf

Organisation for Economic Co-operation and Development. (2016). Mental health systems in OECD countries. Retrieved from http://www.oecd.org/els/health-systems/mental-health-systems.htm

Public Health Agency of Canada. (2014). Economic burden of illness in Canada, 2005-2008. Ottawa, ON: Author.

Smetanin, P., Stiff, D., Briante, C., Adair, C. E., Ahmad, S., \& Khan, M. (2011). The life and economic impact of major mental illnesses in Canada: 2011 to 2041. Unpublished report. Toronto, ON: RiskAnalytica, on behalf of the Mental Health Commission of Canada.

Statistics Canada. (2016). Consumer Price Index, historical summary. Retrieved from http://www.statcan.gc.ca/tablestableaux/sum-som/101/cst01/econ46a-eng.htm 


\title{
Mesurer les coûts agrégés liés à la santé mentale au Canada : un examen de la question
}

\author{
Philip Jacobs \\ University of Alberta \\ Francine Knoops \\ Commission de la santé mentale Canada \\ Alain Lesage \\ Université de Montréal
}

\begin{abstract}
RÉSUMÉ
Depuis 2000, 5 études ont été publiées sur l'estimation des coûts agrégés liés à la santé mentale au Canada, et elles utilisent toutes des méthodes différentes. Comme notre objectif était de comparer ces études et leurs résultats, nous avons conçu un cadre qui regroupe tous les éléments des coûts à évaluer (coûts directs, coûts indirects, paiements de transfert et coûts « humains »). Nous avons tenu compte du fait que les études retenues ne s'appuient pas sur les mêmes paramètres (ex. : la population concernée, la définition de la maladie mentale) ni sur les mêmes éléments de coût. Notre cadre d'analyse permet ainsi d'aider les chercheurs à mieux comprendre les liens que l'on doit établir entre les différents éléments de coûts à considérer et l'utilisation que l'on veut faire de la mesure obtenue. En conclusion, nous soulignons que, pour qu'il soit possible d'obtenir un consensus sur les coûts liés à la santé mentale, il est nécessaire de concevoir et d'utiliser des méthodes standard acceptées par tous.
\end{abstract}

Mots clés : fardeau économique, santé mentale, coût

\begin{abstract}
Since 2000, 5 studies have been published that each purported to estimate aggregate national mental health costs in Canada. Each of these studies used a different method. Our aim was to compare the studies, and we created a framework for the different elements used to assess mental health costs (direct costs,
\end{abstract}

Philip Jacobs, Département de médecine, University of Alberta, Edmonton (Alberta). Francine Knoops, Commission de la santé mentale du Canada, Ottawa (Ontario). Alain Lesage, Département de psychiatrie, Université de Montréal, Montréal (Québec).

Ce projet a été financé grâce à un contrat conclu entre la Commission de la santé mentale du Canada et l'Institute of Health Economics. Les auteurs n'ont aucun intérêt concurrent.

La correspondance concernant cet article devrait être acheminée à Philip Jacobs, Institute of Health Economics, 1200-10405, Jasper Avenue, Edmonton (Alberta), T5J 3N4.Courriel : pjacobs@ihe.ca 
indirect costs, transfer payments, and "human" costs). In addition, each study used different parameters (population covered, diagnosis) and cost components to estimate the economic impact of mental health. Our framework can help analysts to understand the purpose of different cost components. We conclude that to achieve a consensus on the magnitude of mental health costs, we need to use more standardized approaches.

Keywords: Economic burden, mental health, cost

Les décideurs politiques du domaine de la santé mentale doivent composer avec des mesures agrégées différentes et souvent confuses et contradictoires des coûts liés à la santé mentale. Il existe plusieurs estimations du «fardeau économique » que représenterait au Canada les soins de santé mentale, les chiffres allant de 12,3 milliards de dollars par année (Agence de la santé publique du Canada, 2014) à 2,53 billions sur une période de 20 ans (Smetanin et al., 2011). De plus - ce qui ajoute à la confusion — trois études, qui arrivent pourtant à une conclusion semblable, un coût total d'environ 50 milliards de dollars (non ajusté à l'inflation) par année (Conference Board du Canada, 2012; Lim et al., 2008; Commission de la santé mentale du Canada, 2013), s'appuient en fait sur des méthodes et des éléments de coûts très différents; notons aussi que Lim et al. (2008) ont utilisé les coûts de 2001, ce qui porte l'estimation des coûts à 65 milliards (tableau 2) en dollars de 2015. D'ailleurs, Deraspe (2013), dans une étude faite grâce aux ressources de la Bibliothèque du Parlement canadien, a noté que l'absence de consensus sur ce que devraient comporter les diverses catégories de coûts rend impossible la comparaison de diverses études portant sur cette question. La Commission de la santé mentale du Canada (2013), pour sa part, a souligné dans un document le besoin de mesures plus complètes qui permettraient de mieux orienter les politiques et d'évaluer les impacts des estimations budgétaires. Puis, le travail de mise à jour de ce document qu'elle a suite fait avec Faire valoir les arguments en faveur des investissements dans le système de santé mentale du Canada à l'aide de considérations économiques (Commission de la santé mentale du Canada, 2017) a clairement souligné la nécessité de relever le défi lié à l'estimation des coûts en matière de santé mentale; ce travail, comme l'a affirmé la Commission, est essentiel si l'on veut fournir aux décideurs un portrait plus clair des coûts actuels sur lequel s'appuyer pour décider où investir les nouveaux fonds fédéraux destinés à la santé mentale qui sont prévus dans l'Accord sur la santé de 2017.

En fait, il n'existe pas au Canada de normes acceptées par tous en matière de coûts agrégés liés la santé mentale, alors que ces normes existent dans le cas des maladies en général. Il y a des méthodes standard pour mesurer les coûts et évaluer l'impact économique de certaines interventions (Agence canadienne des médicaments et des technologies de la santé, 2016), mais elles ne s'appliquent pas au niveau agrégé. Et, même si des organisations internationales (Commission européenne, Fonds monétaire international, Organisation de développement et de coopération économiques, Nations unies et Banque mondiale, 2009) et des chercheurs américains (Hodgson et Meiners, 1982) ont conçu des normes liées aux coûts de production, ceux-ci ne permettent pas d'utiliser les coûts agrégés liés à la santé pour répondre à des questions précises : selon l'objectif visé, il faut donc utiliser différentes catégories de coûts ou différents éléments de coûts. C'est pourquoi il est essentiel de définir clairement l'objectif d'une étude pour savoir sur quelles mesures de coûts elle devra s'appuyer (Bloom et al., 2011). C'est pour faciliter ce travail que, dans cette recherche, nous faisons une revue de la littérature canadienne sur les coûts agrégés liés à la santé mentale, et que nous 
établissons ensuite quels types de mesures on doit utiliser selon les objectifs que l'on vise. Une fois ces concepts clarifiés, il sera possible de concevoir des mesures et des méthodes standard pour évaluer les coûts agrégés dans le domaine de la santé mentale.

\section{MÉTHODOLOGIE}

Nous avons recueilli les mesures agrégées de la santé mentale au Canada de 2000 à 2015 grâce à notre revue de la littérature et de la littérature grise. Sur la base de cadres utilisés en économique de la santé, nous avons ensuite réparti les types de coûts utilisés dans les études consultées en quatre catégories : les coûts directs, les coûts indirects, les paiements de transfert et les coûts humains. Les deux premières catégories (coûts directs et indirects) ne sont composées que de coûts économiques (les coûts d'utilisation des ressources). Les coûts directs sont les coûts de biens et services, comme les soins hospitaliers, les honoraires des médecins et les produits pharmaceutiques; les coûts indirects sont principalement la valeur des pertes en matière d'activités quotidiennes que subissent les patients et patientes et les aidants et aidantes, autrement dit les coûts des ressources (le temps de travail) dont il n'est pas possible de tirer profit à cause de la maladie. Les chercheurs mesurent habituellement ces pertes en termes de temps de travail plutôt que de loisirs; elles peuvent être liées à de l'absentéisme (la perte de temps de travail) ou à du présentéisme (une diminution de la productivité pendant les heures de travail). Les paiements de transfert, pour leur part, ne constituent pas un coût économique; il s'agit plutôt de transferts de pouvoir d'achat d'un gouvernement à des individus (aucun service n'est échangé ni n'entraîne de perte). Ce sont par exemple les prestations versées en vertu du Régime de pensions du Canada à une personne ayant une invalidité : aucune utilisation de ressources n'est directement associée à ce paiement. Enfin, les coûts humains, qui ne sont pas non plus des coûts économiques, correspondent à une mesure monétaire subjective de la perte de bien-être que subit une personne; c'est par exemple à des fins d'intérêt public, comme dans le cas des directives d'un tribunal, qu'il est utile de donner une valeur monétaire à ce type de pertes. On trouve dans Culyer (2014) des définitions plus détaillées de toutes ces catégories.

Ces catégories de coûts sont liées à différentes méthodes d'évaluation. Les coûts directs sont associés à des biens et services dont le marché permet d'estimer la valeur : il s'agit par exemple des honoraires des médecins, du prix des médicaments et du coût des soins hospitaliers évalués grâce aux groupes de maladies analogues (GMA). Dans le cas des services directement offerts par un gouvernement, on utilise en général une méthode qui s'appuie sur la fonction de production, ce qui permet d'établir les ressources ou les intrants nécessaires pour produire ces services (Commission européenne et al., 2009, p. 438). Les intrants peuvent alors être mesurés en termes de ressources, comme le temps de travail, les fournitures (nécessaires au travail) et le capital, ou en termes de services intermédiaires, comme les hospitalisations et le travail des médecins. On détermine le prix de chaque intrant, que l'on multiplie par la quantité utilisée, et la somme des produits liés à tous les intrants donne le prix total des services (c'est ce qu'on appelle micro-costing, ou évaluation ascendante). On peut également additionner les coûts de toutes les ressources liées à un ensemble de services qui entrent dans un budget donné, puis calculer la moyenne de chacun des services de l'ensemble considéré (c'est ce qu'on appelle évaluation descendante). Les coûts indirects, pour leur part, sont évalués en termes de coûts de remplacement ou de coûts de renonciation des prestataires de soins ou des aidants ou aidantes; il s'agit de la somme que des prestataires de soins or des aidants ou aidantes auraient gagnée grâce à un emploi 
qui se rapproche le plus du leur pendant la période considérée. On peut mesurer le temps de travail perdu soit en termes de coûts de capital humain (la valeur du temps de travail pendant lequel la maladie entraîne une absence du travail) ou en termes de coûts de friction (la valeur de la perte de temps de travail du début de l'absence jusqu'au remplacement). Un paiement de transfert est évalué en termes de la somme d'argent qui est transférée de l'organisme gouvernemental. Les coûts humains sont mesurés de façon subjective.

Par ailleurs, on évalue les coûts de différentes façons selon l'utilisation que l'on souhaite faire des mesures obtenues. On peut chercher à obtenir une mesure du fardeau ou de la charge que constituent les coûts; le fardeau global correspond alors à la mesure monétaire de la perte de ressources ou de la douleur subie à cause de maladie mentale; le fardeau économique, lui, correspond à l'utilisation ou à la perte de ressources liée à la maladie ou à la prestation de soins. On peut ainsi donner différentes significations et faire différentes mesures du fardeau économique. L'une des plus courantes est la somme payée par des assureurs privés pour des services de santé mentale en rapport avec les dépenses totales (pour les coûts directs) en services de santé mentale. Une variante un peu plus restreinte de cette mesure est le montant payé par les individus eux-mêmes (excluant les sommes reçues d'assureurs privés) en rapport avec les dépenses directes totales. On peut également inclure les coûts indirects et les coûts humains dans d'autres types de mesures du fardeau (mais notons que les coûts humains ne sont pas considérés comme faisant partie du fardeau économique). On peut enfin déduire les paiements de transfert faits à des individus des coûts directs et indirects pour obtenir une autre mesure du fardeau : on parle alors de fardeau privé.

Une deuxième utilisation de ces mesures de coûts est l'élaboration de budgets liés à un organisme payeur et qui correspondent alors aux coûts d'un projet donné (offrir un programme élargi de santé mentale communautaire, par exemple). Un budget correspond aux sommes dépensées par un organisme payeur, ce qui inclut les coûts directs et les transferts faits par l'organisme ou par le gouvernement à des individus. Toutefois, dans le domaine de la santé mentale, les services sont fournis et payés par plusieurs organismes, comme les ministères de la santé, les organismes de services sociaux, les ministères de la justice et les ministères de l'éducation ou les commissions scolaires : il est donc difficile d'établir un budget unique pour l'ensemble des coûts.

Un troisième type de mesures des coûts concerne les ressources. Dans ce domaine, la mesure la plus étroite que l'on peut faire du coût d'utilisation de certaines ressources correspond aux coûts des ressources directement utilisées pour réaliser un projet ou mettre en œuvre une politique bien précise. Une politique qui vise la désinstitutionalisation des patients et patientes psychiatriques, par exemple, entraînera une baisse des coûts des hospitalisations mais aussi une hausse des coûts des services offerts dans la communauté, et pourrait aussi entraîner une augmentation des coûts du système judiciaire et des services sociaux. Pour obtenir la mesure réelle de l'utilisation des ressources, il faudrait donc tenir compte à la fois des ressources dont l'utilisation diminue et de celles dont l'utilisation augmente, peu importe qui fournit ces ressources. On peut aussi élargir ce type de mesures en y incluant les coûts indirects liés aux prestataires de soins de santé mentale. Comme les paiements de transfert et les coûts humains ne mesurent pas directement l'utilisation de ressources, on ne les inclut pas dans cette catégorie.

Enfin, l'analyse comparative est un quatrième cas où la mesure des coûts liés à la santé mentale est utile : pensons par exemple à une comparaison de ces coûts par régions, qu'il sera possible de faire grâce aux montants des dépenses directes totales par habitant de chaque région. Le rapport entre les coûts directs 
liés à la santé mentale et les coûts directs de santé peut aussi être un indicateur utile; cette mesure est largement utilisée pour comparer la situation de différents pays, comme le fait par exemple l'Organisation pour la coopération et le développement économiques (2016).

Pour réaliser cette comparaison, nous avons examiné les études des coûts agrégés liés à la santé mentale publiées depuis 2000. Nous avons fait abstraction des maladies ou des troubles mentaux dont rendaient compte ces études et des éléments de coûts qui y sont inclus. Nous avons ajusté les coûts agrégés au niveau des prix de 2015 en utilisant l'indice des prix à la consommation de Statistique Canada (2016). Nous présentons les études retenues et leurs sources de données au tableau 1 et les estimations par catégories de coûts au tableau 2.

Tableau 1

Les études retenues et leurs caractéristiques

\begin{tabular}{|c|c|c|c|}
\hline $\begin{array}{l}\text { Étude et année des } \\
\text { données }\end{array}$ & $\begin{array}{l}\text { Maladies ou types de services } \\
\text { retenus }\end{array}$ & $\begin{array}{l}\text { Population con- } \\
\text { cernée }\end{array}$ & Sources des données \\
\hline $\begin{array}{l}\text { Lim et al. (2008) } \\
\text { Données de } 2001\end{array}$ & $\begin{array}{l}\text { Troubles de l'humeur, troubles } \\
\text { anxieux, schizophrénie, } \\
\text { diagnostiqués ou non, données } \\
\text { autorapportées. }\end{array}$ & $\begin{array}{l}\text { Personnes de } 16 \\
\text { ans et }+\end{array}$ & $\begin{array}{l}\text { Enquête sur la santé dans les collec- } \\
\text { tivités canadiennes, } 2003 \text {, personnes } \\
\text { de plus de } 15 \text { ans. }\end{array}$ \\
\hline $\begin{array}{l}\text { PHAC (2014) } \\
\text { Données de } 2008\end{array}$ & $\begin{array}{l}\text { Large éventail de troubles } \\
\text { neuropsychiatriques; utili- } \\
\text { sation de services liés à la } \\
\text { maladie seulement. }\end{array}$ & $\begin{array}{l}\text { Ensemble de la } \\
\text { population }\end{array}$ & $\begin{array}{l}\text { Données de l'Institut canadien } \\
\text { d'information sur la santé (ICIS) } \\
\text { portant sur les hospitalisations et les } \\
\text { rendez-vous médicaux; temps de } \\
\text { travail perdu : sondages. }\end{array}$ \\
\hline $\begin{array}{l}\text { IHE (2010) } \\
\text { Données de } 2007\end{array}$ & $\begin{array}{l}\text { Ensemble des services de } \\
\text { maladie mentale. }\end{array}$ & $\begin{array}{l}\text { Ensemble de la } \\
\text { population }\end{array}$ & $\begin{array}{l}\text { Données sur les coûts directs : ICIS } \\
\text { et organismes gouvernementaux. }\end{array}$ \\
\hline $\begin{array}{l}\text { Conference Board } \\
\text { (2016) } \\
\text { Données de } 2012\end{array}$ & Dépression et anxiété. & $\begin{array}{l}\text { Personnes ayant } \\
\text { un emploi }\end{array}$ & $\begin{array}{l}\text { Enquête sur la santé dans les col- } \\
\text { lectivités canadiennes; estimations } \\
\text { des coûts faites par le Conference } \\
\text { Board. }\end{array}$ \\
\hline $\begin{array}{l}\text { Risk Analytica pour } \\
\text { CSMC/MHCC } \\
\text { (Smetanin et al., } \\
\text { 2011) }\end{array}$ & $\begin{array}{l}\text { Deux catégories : } \\
\text { A. Troubles cognitifs, incluant } \\
\text { la démence. } \\
\text { B. Autres troubles mentaux. }\end{array}$ & $\begin{array}{l}\text { Même chose que } \\
\text { IHE (2010) }\end{array}$ & $\begin{array}{l}\text { Données sur les troubles cognitifs : } \\
\text { Hollander (2002); sur d'autres } \\
\text { troubles mentaux : Jacobs (2010). }\end{array}$ \\
\hline
\end{tabular}




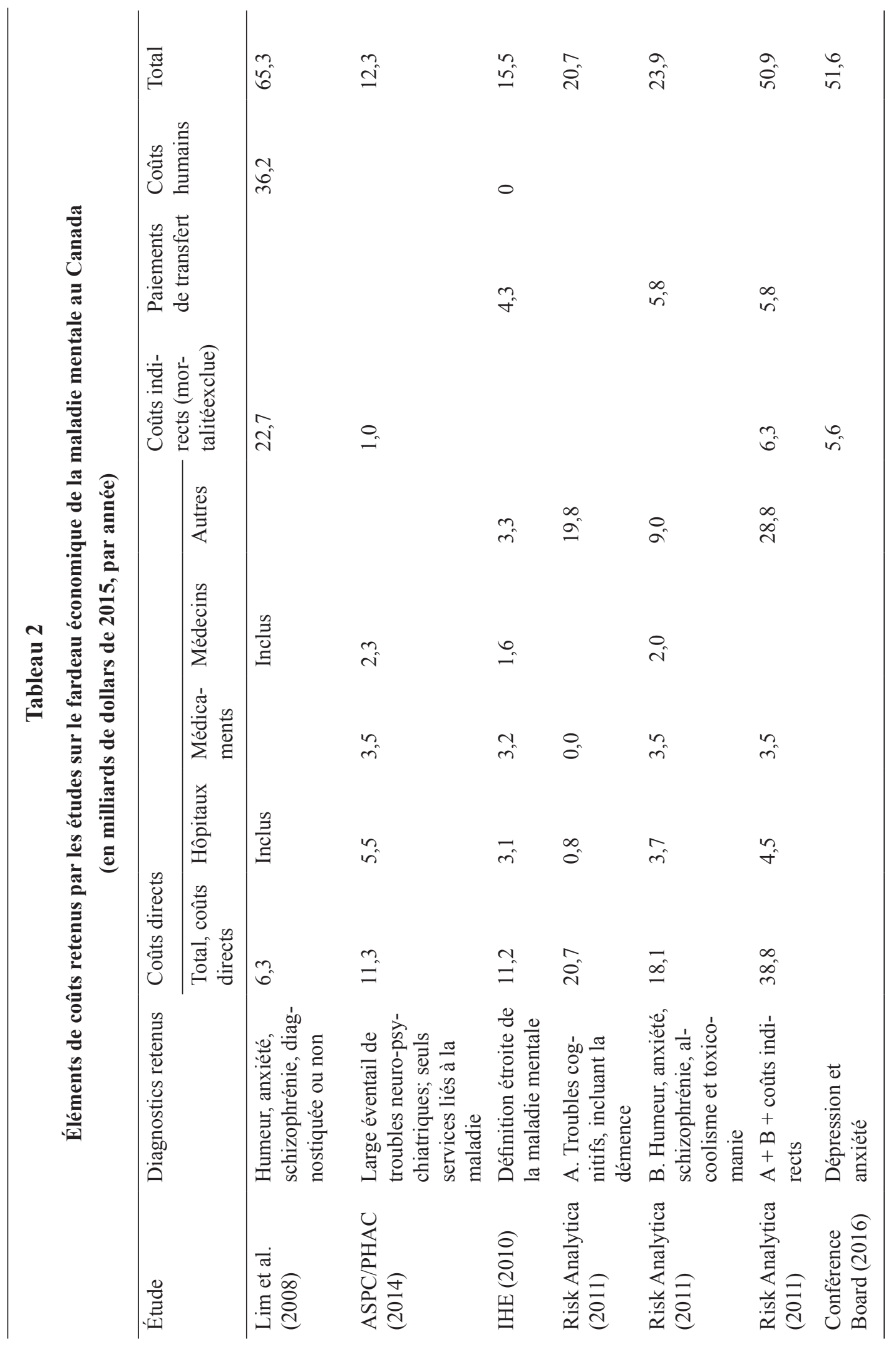




\section{RÉSULTATS}

Nous avons retenu cinq études sur les coûts de la santé mentale au Canada : elles sont présentées au tableau 1. Précisons que Lim et al. (2008), l'Institute of Health Economics (IHE) (2010) et le Conference Board (2012) s'appuient sur une définition étroite de la maladie mentale - anxiété, schizophrénie et alcoolisme et toxicomanie. L'Agence de la santé publique du Canada (2014) utilise pour sa part une définition très large qui inclut les troubles neuropsychiatriques. RiskAnalytica (Smetanin et al., 2011) utilise deux définitions différentes : une plus étroite, semblable à celle de l'IHE, qui permet de mesurer les coûts liés aux maladies mentales graves, et une plus large, qui inclut les troubles cognitifs, dont la démence. On retrouve ces différentes définitions aux tableaux 1 et 2 . Les éléments de coûts varient aussi beaucoup selon les études (voir le tableau 2). Les sources des données sont indiquées au tableau 1.

On vient de voir qu'il y a plusieurs façons de définir les « coûts économiques » de la maladie mentale et, comme le montre le tableau 2, les estimations de ces coûts varient aussi beaucoup : elles vont (en dollars de 2015) de 13,5 milliards de dollars (ASPC/PHAC, 2014) à 65,3 milliards (Lim et al., 2008). Les études s'appuient toutefois sur des ensembles de maladies et d'éléments de coût différents. Par exemple, dans le cas des deux estimations les plus basses, l'Agence de la santé publique du Canada (ASPC/PHAC, 2014) tient compte du nombre le plus grand de maladies, dont presque tous les troubles neurologiques, alors que l'estimation de l'Institute of Health Economics (2010) est basée sur une définition plus étroite de la maladie mentale. En plus, l'Agence de la santé publique du Canada inclut les coûts indirects dans son estimation, alors que l'IHE les exclut (en incluant toutefois les paiements de transfert). De façon similaire, RiskAnalytica (Smetanin et al., 2011) et le Conference Board (2012) arrivent à un chiffre d'un peu plus de 50 milliards de dollars, mais RiskAnalytica utilise une définition très large de la maladie, incluant la démence, alors que le Conference Board ne tient compte que de la dépression et de l'anxiété; de plus, les estimations de RiskAnalytica sont d'abord axées sur les dépenses liées à des services, tout en comportant une composante indirecte pour la démence. Enfin, l'étude de Lim et al. (2008) s'appuie sur une définition étroite de la maladie, mais inclut les coûts indirects et les coûts humains, ce qui contribue pour beaucoup à l'ampleur de l'estimation obtenues qui se chiffre à 65,3 milliards de dollars.

Mentionnons enfin que les résultats varient aussi selon les coefficients d'inflation utilisés. RiskAnalytica (Smetanin et al., 2011) fonde ses estimations sur un seul taux d'inflation, établi en 2005, appliqué à toutes les années; or, 2005 est une année où le taux d'inflation était plus élevé qu'au cours des années suivantes. Pour notre part, nous utilisons l'indice général des prix à la consommation, qui est disponible pour toutes les années et que l'on peut appliquer à toutes les études.

\section{DISCUSSION}

On voit donc que plusieurs études ont permis de faire des estimations des coûts de la maladie mentale au Canada. D'une part, les estimations que présentent certaines d'entre elles sont très différentes, et, d'autre part, même quand certaines en arrivent à des estimations similaires, les éléments qui sont pris en compte sont très différents, ce qui soulève des questions sur la façon adéquate d'estimer ces coûts. Pour établir cette analyse, nous avons examiné et comparé les éléments et les estimations de cinq études que nous avons retenues. Cela nous permet de montrer qu'il existe divers types de mesures des coûts agrégés liés à la santé 
mentale, et que c'est l'utilisation que l'on veut faire de ces mesures qui détermine celui qui est approprié dans chaque cas. Quand on définit les différents objectifs qui peuvent être liés à l'utilisations de ces mesures, et que l'on considère les coûts qui peuvent y être associés, on obtient une meilleure idée de ceux dont il faut alors tenir compte. Chacune des utilisations que l'on veut faire de ces mesures exige en effet de tenir compte de certains coûts en particulier - en d'autres mots, aucune série de coûts ne peut convenir à toutes les utilisations possibles.

Par exemple, si l'objectif visé est l'établissement du budget d'un organisme gouvernemental, il faut tenir compte des coûts directs et des paiements de transfert, qui correspondent à des dépenses de cet organisme. Si la question que l'on se pose en est plutôt une d'utilisation de ressources, alors l'estimation doit inclure les coûts directs et indirects; mais, même dans ce cas, cela peut varier : s'il s'agit de ressources publiques, par exemple, seuls les coûts directs sont pertinents - par exemple, si des chercheurs veulent déterminer l'impact en termes de ressources de la fermeture d'un certain nombre de lits dans des hôpitaux et du transfert de ces soins dans la communauté, alors ils ne tiendront compte que des coûts directs. De la même façon, si l'on cherche à estimer les coûts qu'implique le remplacement de soins spécialisés par des soins primaires, il faut estimer les coûts directs dans chacun des cas et comparer les mesures obtenues. Dans le domaine de la santé mentale, toutefois, quand il est question d'utilisation de ressources, l'estimation ne peut pas s'appuyer sur les seuls coûts liés au secteur de la santé, puisque la maladie mentale a des répercussions également dans les domaines de l'éducation, de la justice pénale et des services sociaux : il faut donc tenir compte aussi des coûts liés à ces services. De plus, les questions d'utilisation de ressources sont souvent abordées sous l'angle du rapport coût-efficacité, et rarement formulées en termes agrégés.

On utilise aussi les estimations de coûts agrégés pour mesurer le fardeau économique. La plupart des études que nous avons examinées visaient d'ailleurs à mesurer le fardeau économique de la maladie mentale; ainsi, celle du Conference Board est axée sur les coûts de l'absentéisme et du présentéisme, et celle de RiskAnalytica (Smetanin et al., 2011) avait pour but d'évaluer les coûts futurs directs de la maladie mentale et de la démence, deux indicateurs du fardeau économique. On peut également évaluer le fardeau économique en tenant compte des coûts liés à la prestation de soins, qui sont des coûts de ressources. Et, dans l'étude de Lim et al. (2008), on tient aussi compte des coûts humains en tant qu'éléments du fardeau; notons toutefois qu'il ne s'agit pas à proprement parler de coûts de ressources et que ces coûts ne font donc pas partie du fardeau économique de la maladie mentale. Enfin, les estimations de coûts sont essentielles dans les analyses comparatives. L'étude de l'Institute of Health Economics (2010) avait ainsi pour objectif d'établir les ratios coûts des soins de santé mentale / coûts totaux des soins de santé dans divers pays à des fins de comparaison; la plupart des pays ne tiennent compte que des coûts directs à cet effet (Organisation pour la coopération et le développement économiques, 2016). Les analyses comparatives en matière de santé mentale s'appuient aussi souvent sur la mesure des coûts directs par habitant (Institute of Health Economics, 2010); on utilise par exemple cette mesure pour comparer la quantité de ressources utilisées dans diverses provinces canadiennes.

\section{CONCLUSION}

Évaluer les coûts agrégés liés à la santé mentale pose deux problèmes majeurs : l'absence de normes et le manque de données adéquates. En effet, si d'autres États ont établi des normes à cette fin, aucune étude 
canadienne ne les utilise. Les chercheurs canadiens pourraient par exemple s'inspirer du Système de comptabilité nationale établi pars divers organismes internationaux (Commission européenne et al., 2009) pour définir des normes en matière de données économiques liées aux coûts directs. On pourrait aussi s'appuyer sur ce qu'a publié le United States Public Health Service à propos des normes qui permettent de mesurer le fardeau économique de la maladie (Hodgson et Meiners, 1982). Toutefois, cela ne réglerait pas l'ensemble du problème, puisque l'utilisation de ces normes nécessite de meilleures données sur l'utilisation des services de santé mentale, et que les données canadiennes disponibles sur les services de soins de santé ambulatoires et communautaires sont actuellement insuffisantes - les meilleures données dont on dispose actuellement sont celles que recueillent les services de santé sur des soins dits médicalement nécessaires. Dans le domaine de la santé mentale, les données liées à plusieurs services, y compris ceux que financent les ministères de la santé, ne sont pas rendues publiques; de plus, des données sur les coûts de services liés à la santé mentale mais qui dépendent d'organismes non liés au système de santé, comme les ministères responsables de la justice et des services sociaux, ne sont pas non plus disponibles.

\section{RÉFÉRENCES}

Agence canadienne des médicaments et des technologies de la santé. (2016). Guide pour l'évaluation des couts des ressources en soins de santé dans le contexte canadien (2e éd.). Ottawa, ON : Auteur.

Agence de la santé publique du Canada. (2014). Le fardeau économique de la maladie au Canada, 2005-2008. Ottawa, ON : Auteur.

Bloom, D. E., Cafiero, E. T., Jané-Llopis, E., Abrahams-Gessel, S., Bloom, L. R., Fathima, S., [. . .] Weinstein, C. (2011). The global economic burden of noncommunicable diseases. Genève, Suisse : World Economic Forum.

Commission de la santé mentale du Canada. (2013). La nécessité d'investir dans la santé mentale au Canada. Calgary, AB : Auteur. Récupéré de https://www.mentalhealthcommission.ca/sites/default/files/2016-06/Investing_in_ Mental_Health_FINAL_FRE.pdf

Commission de la santé mentale du Canada. (2017). Faire valoir les arguments en faveur des investissements dans le système de santé mentale du Canada à l'aide de considérations économiques. Calgary, AB : Auteur. Récupéré de https://www.mentalhealthcommission.ca/sites/default/files/2017-03/case_for_investment_fr.pdf

Commission européene, Fonds monétaire international, Organisation de dèveloppement et de coopèration èconomiques, Nations unies et Banque mondiale. (2009). Système de comptabilité nationale 2008. New York, NY : Auteurs.

Conference Board du Canada. (2012). Mental health issues in the labour force: Reducing the economic impact on Canada. Ottawa, ON : Auteur.

Culyer, A. J. (2014). The dictionary of health economics ( $3^{e}$ éd.). Cheltenham, Angleterre : Edward Elgar.

Deraspe, R. (2013). Questions d'actualité en santé mentale au Canada_l'impact économique de la maladie mentale. Publication no 2013-87-F. Ottawa, ON : Bibliothèque du Parlement.

Hodgson, T. A. et Meiners, M. R. (1982). Cost-of-illness methodology: A guide to current practices and procedures. Memorial Fund Quarterly, Health and Society, 60(3), 429-462.

Institute of Health Economics. (2010). The cost of mental health and substance abuse services in Canada. Edmonton, $\mathrm{AB}:$ Auteur.

Lim, K.-L., Jacobs, P., Ohinmaa, A., Schopflocher, D. et Dewa, C. S. (2008). A new population-based measure of the economic burden of mental illness in Canada. Chronic Diseases in Canada, 28(3), 92-97.

Organisation pour la coopération et le développement économiques. (2016). Mental health systems in OECD countries. Récupéré de http://www.oecd.org/els/health-systems/mental-health-systems.htm

Smetanin, P., Stiff, D., Briante, C., Adair, C. E., Ahmad, S. et Khan, M. (2011). The life and economic impact of major mental illnesses in Canada: 2011 to 2041. Rapport inédit. Toronto, ON : RiskAnalytica, pour la Commission de la santé mentale du Canada.

Statistique Canada. (2016). Indice des prix à la consommation, aperçu historique. http://www.statcan.gc.ca/tablestableaux/sum-som/102/cst01/econ46a-fra.htm 